\title{
Managing the Race Structure of Phytophthora parasitica var. nicotianae with Cultivar Rotation
}

\author{
M. J. Sullivan, National Weed Management Laboratory, United States Department of Agriculture APHIS PPQ \\ CPHST, Fort Collins, CO 80526; T. A. Melton, Associate State Program Leader, AgNR/CRD, Cooperative Exten- \\ sion Service, North Carolina State University, Raleigh 27695-7602; and H. D. Shew, Department of Plant Pathology, \\ North Carolina State University, Raleigh 27695
}

\begin{abstract}
Sullivan, M. J., Melton, T. A., and Shew, H. D. 2005. Managing the race structure of Phytophthora parasitica var. nicotianae with cultivar rotation. Plant Dis. 89:1285-1294.

Deployment of tobacco cultivars with single-gene, complete resistance to race 0 of the tobacco black shank pathogen, Phytophthora parasitica var. nicotianae, has resulted in a rapid increase in the occurrence of race 1 of the pathogen in North Carolina. Cultivar-rotation studies were conducted in three fields to assess how different levels and types of resistance affected the race structure and population dynamics of the pathogen when deployed in fields initially containing single or mixed races of the pathogen. In a field with both races present, a high level of partial resistance in cv. K 346 was most effective in reducing disease and decreasing the proportion of race 1 in the pathogen population. The deployment of complete resistance in $\mathrm{cv}$. NC 71 resulted in intermediate levels of disease control and race 1 became the predominate race. The $\mathrm{cv}$. K 326 , with a low level of partial resistance, had the highest levels of disease, and race 0 was the dominant race recovered. In a field where no race 1 was detected initially, disease incidence was high with the use of partial resistance. Complete resistance was very effective in suppressing disease, but race 1 was recovered after only one growing season. By the end of the third growing season, race 1 was recovered from most treatments where single-gene resistance was deployed. A high level of partial resistance was most effective in suppressing disease in a field where race 1 initially was the predominant race. A rotation between cultivars with single-gene resistance and cultivars with a high level of partial resistance should provide the most effective approach to black shank management. This rotation will reduce disease incidence and minimize race shifts in the pathogen and, over time, should prolong the usefulness of the $P h$ gene for black shank control in commercial production of tobacco.
\end{abstract}

Additional keywords: Fla. 301 Nicotiana tabacum

Black shank, caused by the soilborne pathogen Phytophthora parasitica Dastur var. nicotianae (Breda de Haan) Tucker (syn. P. nicotianae van Breda de Haan var. nicotianae G. M. Waterhouse, P. nicotianae van Breda de Haan) is one of the most destructive diseases of tobacco (Nicotiana tabacum) in the southeastern United States. The disease also is present in most tobacco-producing regions of the world and can result in yield losses on all tobacco types $(10,18)$. Since its initial report in North Carolina in 1931, the disease has caused economically important losses in

Corresponding author: M. J. Sullivan

E-mail: Melinda.J.Sullivan@aphis.usda.gov

This research was funded in part by the North Carolina Tobacco Research Commission, the North Carolina Tobacco Foundation, Inc., and the North Carolina Agricultural Research Service. Support was provided by the E. G. Moss graduate fellowship to M. J. Sullivan during part of this project.

Accepted for publication 10 July 2005

DOI: 10.1094/PD-89-1285

(C) 2005 The American Phytopathological Society the state, with annual losses in the last 10 years averaging over $\$ 10$ million $(18,19)$. Infection of roots, stems, and leaves can occur at any stage of plant growth, resulting in root necrosis, wilting, chlorosis, stem lesions, stunting, and plant death $(11,18)$.

Black shank is managed by using an integrated approach that includes cultural practices, fungicides, and host resistance (19). Multiple crop plants used in rotation with tobacco are effective in reducing populations of the pathogen, but none are similar to tobacco in income returned per hectare (19). In addition, in the absence of other control practices, even long rotations are not highly effective, because $P$. parasitica var. nicotianae can survive in soil for 5 years or longer in the absence of tobacco $(2,18)$. Fungicides effectively reduce disease losses, but costs can exceed $\$ 250.00 /$ ha for control in a highly infested field, and disease losses still may be high (19). In addition, the primary fungicides used for black shank control, mefenoxam and metalaxyl, are prone to resistance development (21).

The most widely used method of control for black shank is host resistance. Multiple sources and types of resistance are available to growers. In 1931, Tisdale intraspecifically transferred black shank resistance to the cigar wrapper cultivar Florida 301 (Fla. 301) (32). This resistance, the principal source of resistance used in tobacco breeding since the 1940s, is complex and may be controlled by partially dominant genes that are expressed to varying degrees due to the presence of modifier genes in the susceptible parent $(8,20,34)$ Thus, tobacco cultivars that contain Fla. 301 resistance vary in level of resistance from low to high. This type of resistance, referred to as partial resistance $(6,15,16,24,29)$, is effective against all races of $P$. parasitica var. nicotianae $(6,15,29,34)$.

Single-gene resistance also has been incorporated interspecifically into $N$. $t a-$ bacum cultivars. Sources of single-gene resistance to $P$. parasitica var. nicotianae include genes from $N$. longiflora Cav. and $N$. plumbaginifolia $(1,5,7,33)$. The single genes identified in N. plumbaginifolia and $N$. longiflora provide complete resistance to race 0 , but provide no resistance to race 1 of $P$. parasitica var. nicotianae (3). The burley breeding line L8, which contains the resistance gene from $N$. longiflora, has been used commercially only in hybrids because of a severe physiologic spotting reaction conditioned by a recessive gene pair present in L8 (33); this trait is not expressed in hybrids. The flue-cured breeding line North Carolina 1071 (NC 1071) was developed from an interspecific cross with $N$. plumbaginifolia and contains the single-gene, complete resistance to race 0 of $P$. parasitica var. nicotianae (3). This gene was introduced into commercially acceptable flue-cured cultivars beginning in the 1980s.

Races 0 and 1 of $P$. parasitica var. nicotianae have been reported in North Carolina and most of the major tobaccogrowing areas of the United States. The first report of race 1 of $P$. parasitica var. nicotianae was from burley tobacco in Kentucky in 1954, where it was found in association with plantings of breeding lines with resistance derived from $N$. longiflora $(1,33)$. Races 0 and 1 have been observed in the North Carolina burleyproducing area for many years. Apple (1) first described race 1 of $P$. parasitica var. nicotianae from flue-cured tobacco in 
North Carolina. Isolates nonpathogenic to $N$. plumbaginifolia were referred to as race 0 , and isolates that infected $N$. plumbaginifolia were referred to as race 1 . The race 1 isolates were observed in breeding nurserbreeding lines with the $N$. plumbaginifolia gene were being evaluated for disease resistance and agronomic traits (3). Because race 1 was detected after only a single year of planting lines with this resistance gene, Apple felt that this type of resistance would be of limited utility unless it was combined with another source of resistance that would provide protection against race 1 . Therefore, commercial cultivars that contained this resistance gene were not released at that time (3).

In 1987, the flue-cured tobacco cv. and found to provide an excellent source of resistance to $P$. parasitica var. nicotianae. Initially, the origin of the resistance and its mode of inheritance were not known. Subsequent research determined that the resistance was highly effective against race 0 and was controlled by a single dominant gene, later described as the $P h$ gene (6). The origin of the gene was determined to be $N$. plumbaginifolia, and it was present in combination with a low level of partial resistance from Fla. 301(15). In Georgia, the release of Coker 371-G led to reports of race 1 from counties across the entire tobacco-growing region (9). Although widely planted in Georgia, this cultivar failed to gain wide acceptance with growers in North Carolina due to poor agronomic traits, including premature flowering, small root systems that often led to lodging, thin leaves, poor curing properies in the 1960s, when NC 1071 and other Coker 371-Gold (C 371-G) was released

ties, and low yields. In addition, other disease management options were effective in reducing losses to black shank. The flue-cured cultivar NC 71, which also contains the $P h$ gene, was released for commercial use in 1997. This cultivar has been deployed widely in North Carolina and other states due to its combination of high disease resistance to race 0 , high yields, and excellent quality.

Of the two races of $P$. parasitica var. nicotianae present in North Carolina, race 0 has been the predominant race in the flue-cured area of North Carolina since 1931 (18). Although race 1 was observed in breeding nurseries in the 1960 s, it was not observed widely in production areas until cultivars containing the $P h$ gene (i.e., NC 71) were released in the 1990s. Disease losses were observed in some fields planted to these resistant cultivars, which was found to be due to increases in the proportion of race 1 in these fields (19). Deployment of this type of resistance continues to increase and, in 2004, it was present in almost $60 \%$ of the flue-cured production area in North Carolina. The increase in race 1 in the flue-cured production areas and an effort to preserve the effectiveness of the $P h$ gene against race 0 of the pathogen prompted this study. Our objective was to ascertain the short- and long-term effects of $P h$ gene deployment on the race structure and population dynamics of the tobacco black shank pathogen.

\section{MATERIALS AND METHODS}

Rotation studies. Four-year rotation studies were conducted in a mixed-race field of $P$. parasitica var. nicotianae in

Table 1. Cultivar rotation treatments in the Edgecombe and Guilford County field sites over the 4-year study ${ }^{\mathrm{a}}$

\begin{tabular}{lcccccccc}
\hline & \multicolumn{8}{c}{ Treatment } \\
\cline { 2 - 9 } Year & $\mathbf{1}$ & $\mathbf{2}$ & $\mathbf{3}$ & $\mathbf{4}$ & $\mathbf{5}$ & $\mathbf{6}$ & $\mathbf{7}$ & $\mathbf{8}$ \\
\hline $1^{\mathrm{b}}$ & K 326 & NC 71 & K 346 & NC 71 & NC 71 & NC 71 & NC 71 & K 326 \\
2 & K 326 & NC 71 & K 346 & K 346 & K 326 & K 346 & K 326 & NC 71 \\
3 & K 326 & NC 71 & K 346 & NC 71 & NC 71 & K 346 & K 326 & K 326 \\
4 & K 326 & NC 71 & K 346 & NC 71 & NC 71 & NC 71 & NC 71 & NC 71 \\
\hline
\end{tabular}

${ }^{a}$ Cultivars with varying levels and types of resistance: $\mathrm{K} 326=$ low level of partial resistance, $\mathrm{K} 346=$ high level of partial resistance, and NC $71=$ complete $(P h)$ gene resistance and a low level of partial resistance.

${ }^{\mathrm{b}}$ Edgecombe County followed the year-1 through year-4 rotation treatments from 1998 through 2001. Guilford County followed year-1 through year-2 rotation treatments from 2000 through 2001.

Table 2. Cultivar rotation treatments in the Duplin County field site over the 4-year study ${ }^{\mathrm{a}}$

\begin{tabular}{lcccccccc}
\hline & \multicolumn{8}{c}{ Treatment } \\
\cline { 2 - 9 } Year & $\mathbf{1}$ & $\mathbf{2}$ & $\mathbf{3}$ & $\mathbf{4}$ & $\mathbf{5}$ & $\mathbf{6}$ & $\mathbf{7}$ & $\mathbf{8}$ \\
\hline $1^{\mathrm{b}}$ & K 326 & NC 71 & K 346 & K 346 & K 326 & K 346 & K 326 & NC 71 \\
2 & K 326 & NC 71 & K 346 & NC 71 & NC 71 & NC 71 & NC 71 & K 326 \\
3 & K 326 & NC 71 & K 346 & K 346 & K 326 & K 346 & K 326 & NC 71 \\
4 & K 326 & NC 71 & K 346 & NC 71 & NC 71 & K 346 & K 326 & K 326 \\
\hline
\end{tabular}

${ }^{a}$ Cultivars with varying levels and types of resistance: $\mathrm{K} 326=$ low level of partial resistance, $\mathrm{K} 346=$ high level of partial resistance, and NC $71=$ complete $(P h)$ gene resistance and a low level of partial resistance.

${ }^{b}$ Duplin County followed the rotation treatments from year 1 (2000) through year 4 (2003).
Edgecombe County, NC from 1998 through 2001, and in a race-0 field in Duplin County, NC from 2000 through 2003. A 4-year cultivar rotation study was begun in a predominately race-1 field Guilford County in 2000, but the field was removed from the study after the second year due to construction of bulk barns on and near the field. Three cultivars, with different levels and types of resistance, were used throughout this study: K 326, with a low level of partial resistance to both race 0 and race $1 ; \mathrm{K} 346$, with a high level of partial resistance to both races; and NC 71, with complete resistance from the $P h$ gene to race 0 and a low level of partial resistance (19). The levels of partial resistance in these cultivars, all derived from Fla. 301 as noted above, were assigned to these cultivars by extension specialists based on disease incidence in a number of field locations over many years in North Carolina. All three cultivars are widely used in the flue-cured production areas in North Carolina (19). These three cultivars were planted continuously over the duration of the study or were rotated such that cultivars with partial and complete resistance were planted in specific sequences (Tables 1 and 2).

The Edgecombe County field experiment was established at the Upper Coastal Plain Research Station, Rocky Mount, NC. The soil type is a Goldsboro fine sandy loam (fine-loamy, siliceous, thermic, Aquic Paleudult) that was naturally infested with race 0 of the pathogen and a low level of race 1 . Plots were four rows wide $(1.22-\mathrm{m}$ row spacing) by $13.72 \mathrm{~m}$ long and were arranged in a randomized complete block design (RCBD) with five replications per treatment. Plots received a supplemental infestation of race 1 in 1998 by uniformly distributing pathogen-colonized oat grains (approximately $500 \mathrm{~cm}^{3}$ per four-row plot) through the field in mid-June during the first year of the test. Data on race structure were not collected at the end of the 1998 season because of the addition of race 1 inoculum during the early part of the growing season. The field was transplanted on 11 May 1998, 5 May 1999, 2 May 2000, and 15 May 2001.

The Duplin County field experiment, in the lower coastal plain region of North Carolina, was established in 2000 in a grower field. The soil type is a Norfolk/Foreston loamy sand (fine-loamy, kaolinitic, thermic, Typic Kandiudult) that was naturally infested with the pathogen and contained only race 0 based on preliminary baseline assays from soil collected prior to planting. Soil samples were collected from each plot in the spring of 2000 and subjected to pathogen population quantification and race determination as described below. Plots were four rows wide (1.22-m row spacing) by $15.24 \mathrm{~m}$ long and were arranged in an RCBD with five replications per treatment. The field 
was transplanted on 26 April 2000, 27 April 2001, 24 April 2002, and 29 April 2003.

The Guilford County field experiment, in the piedmont region of North Carolina, was established in 2000 in a grower field. The soil type is a Mecklenburg sandy clay loam (fine, mixed, thermic, Ultic Hapludalf) that was infested naturally with both race 0 and race 1 . Based on baseline levels, however, the field was predominately race 1 . Plots were four rows wide (1.12-m row spacing) by $13.72 \mathrm{~m}$ long, arranged in an RCBD with six replications per treatment. The field was transplanted on 17 May 2000 and 15 May 2001.

Stand counts were made in each plot approximately 2 weeks after transplanting. Disease incidence (percent symptomatic plants) was recorded three to four times throughout the growing season in each field, with the final disease incidence recorded before last harvest. Yield data were not collected from these tests. Recommended practices for tobacco production were followed, except that the plants were not topped (flower heads removed) and no chemicals were applied to prevent growth of axillary buds at leaf nodes (14). Additionally, fenamiphos (Nemacur 3E; Bayer Crop Science, Kansas City, MO) was applied at 18.7 liters/ha for nematode control in 2000 and 2001 at the Edgecombe County field, whereas 1,3-dichloropropene (Telone II; Dow Agrosciences, Indianapolis, IN) was applied in 2001 at 56.1 liters/ha and 1,3-dichloropropene and chloropicrin (Telone C-17; Dow Agrosciences) was applied in 2002 and 2003 at 98.2 liters/ha in the Duplin County field to control nematodes. Telone II and Telone C-17 were applied on 5 April 2001, 1 April 2002, and 27 March 2003. The air temperature was $24.4,25.5$, and $18.3^{\circ} \mathrm{C}$, the soil temperature was $14.4,15.5$, and $15.5^{\circ} \mathrm{C}$, and the soil moisture was 13.6 , 12.7 , and $12.7 \%$ in 2001, 2002, and 2003, respectively. The material was injected from a single outlet on a single shank $20.32 \mathrm{~cm}$ below the soil surface while a ridge was being formed, resulting in a final depth of $35.56 \mathrm{~cm}$.
Pathogen population quantification and race determination. Soil samples were collected from the center two rows of each four-row plot with a 3-cm-diameter soil probe. Samples were taken within 1 week of final harvest each year. Ten soil cores were collected along a ' $Z$ ' pattern from the two center rows of each plot. The soil samples were bulked and then transported to the lab in coolers. Coolers were stored at room temperature for no more than 4 days before the soil was assayed. Soil samples were mixed thoroughly prior to assay. Inoculum density was determined by suspending a 1-g sample in $25 \mathrm{ml}$ of deionized water, then dispensing the suspension onto five petri plates of PARPH semi-selective medium (5\% V8 juice as the basal medium amended with pentachloronitrobenzene, hymexazol, ampicillin, rifampcin, and pimiricin; 17,28). Three 1-g subsamples were assayed from each sample. After $48 \mathrm{~h}$, the soil suspension was washed from each plate. The plates then were allowed to incubate at room temperature for 24 additional hours, after which $P$.
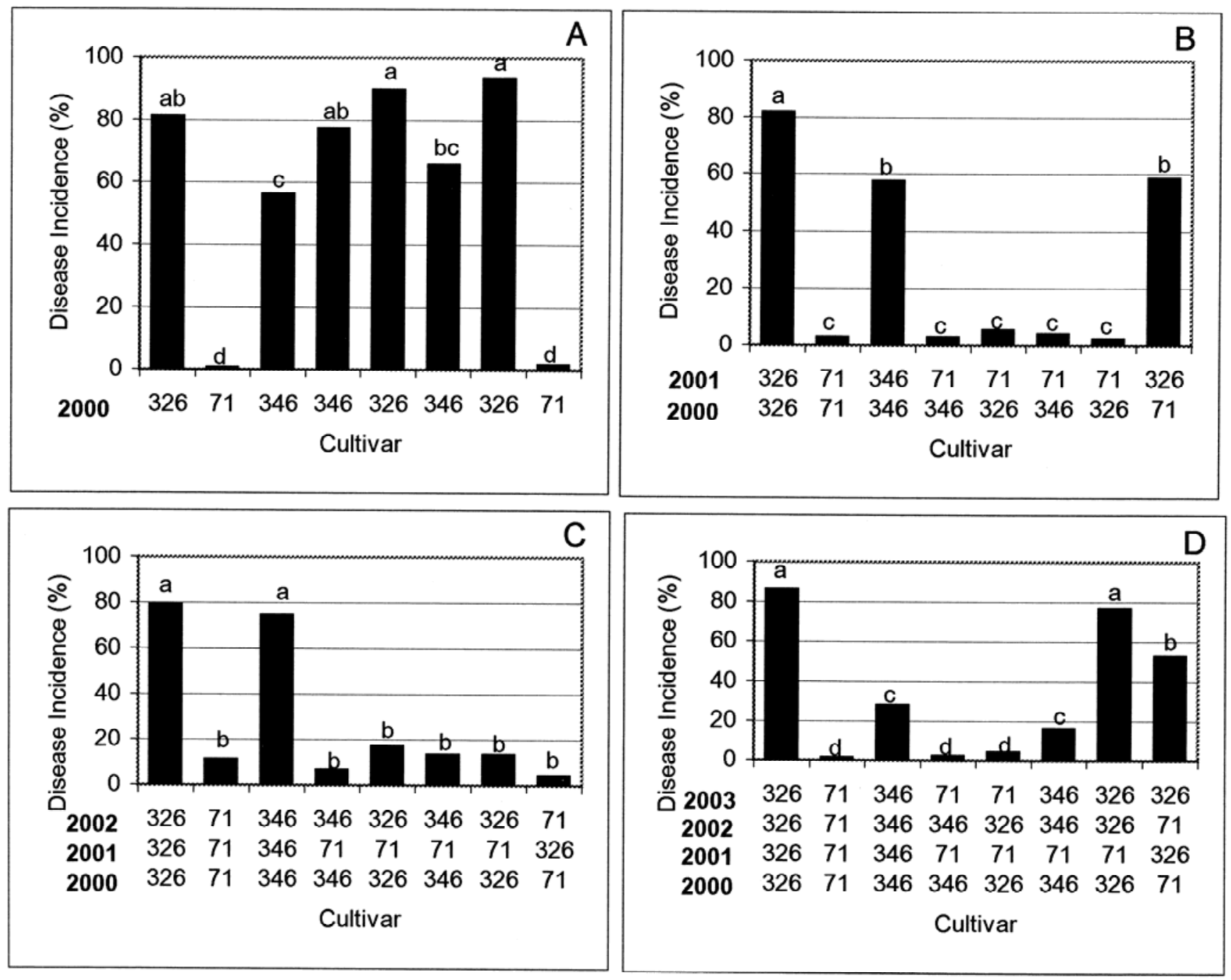

Fig. 1. A-D, Final disease incidence from 2000 through 2003 at the Duplin County field, where race 0 was determined to be predominant. Bars are the average of five replications per treatment per season. Bars with the same letter do not differ significantly (Waller-Duncan $k=100$ ). 
parasitica var. nicotianae colonies were enumerated and transferred. The number of propagules of the pathogen per gram of soil was determined by averaging the number of colonies in each of the 1-g samples after correcting for soil moisture. A minimum of 10 colonies from each plot, for a total of 50 colonies per treatment, were transferred to fresh PARPH. Additional transfers were made to obtain pure cultures of $P$. parasitica var. nicotianae. If 10 propagules/g were not recovered from the initial soil assay, the soil was assayed additional times until 10 propagules were recovered from each plot. The only exception to this was the 2001 samples from Duplin County, when three of the treatments had no recoverable propagules after assaying the soil on three separate occasions. All isolates also were plated on nutrient agar to test for the presence of bacteria prior to transfer to $5 \%$ clarified carrot agar. Carrot juice (Hollywood Carrot Juice or The Hain Celestial Group Inc., Melville, NY) was clarified by filtering the juice through diatomaceous earth (Celite 545; Fisher Scientific, Fair Lawn, NJ). The filtrate $(50 \mathrm{ml})$ was added to
$950 \mathrm{ml}$ of deionized water and $20 \mathrm{~g}$ of Bacto Agar (Difco Laboratories, Detroit), then sterilized in an autoclave prior to pouring into petri plates.

To determine the race of each isolate, a host differential was used that included four cultivars or breeding lines of tobacco: Hicks (susceptible), K 326 (low level of partial resistance), NC 1071 (N. plumbaginifolia gene), and Ky $14 \times$ L8 $(N$. longiflora gene). Plants of each differential cultivar were seeded into a flat containing potting mix (Metro mix 220; The Scotts Company, Marysville, $\mathrm{OH}$ ) and allowed to grow for 3 weeks. After 3 weeks, the plants were transplanted into cell packs ( 72 cells, 4 by 4 by $5 \mathrm{~cm}$ ) containing a $1: 1: 1$ (vol:vol:vol) mixture of steam-pasteurized soil, Metro mix (W. R. Grace), and coarse builder's sand. All plants were watered daily, fertilized as necessary with 20-20-20 water-soluble fertilizer (Peter's), and allowed to grow an additional 7 to 10 days before inoculation.

Inoculum was prepared by placing oat grains sterilized on three consecutive days onto a 3-day-old carrot agar culture of each isolate of $P$. parasitica var. nicotianae collected from the soil assays each year. The oat grains were left on the cultures for 9 days at room temperature. Twenty-four oat grains then were removed from each plate using sterile technique and used as inoculum for race determination. Three 4week-old plants of each genotype were root inoculated with each isolate in the greenhouse by placing two colonized oat grains into each 4-by-4-by-5-cm cell. Roots were not damaged prior to inoculation. After 14 days, plants were scored for the presence or absence of symptoms and determined to be either race 1 or race 0 . Race 1 was defined by the ability to cause disease on NC 1071 and Ky $14 \times$ L8. Race 0 did not cause disease on either of these hosts, but caused disease on the other two cultivars. Race 1 also caused disease on Hicks and K 326.

Analysis of variance was performed on the disease incidence and inoculum density data using the PROC GLM procedure of SAS (version 8e; SAS Institute, Cary, NC), and means separation was conducted using the Waller-Duncan $K$ ratio test $(k=100)$.
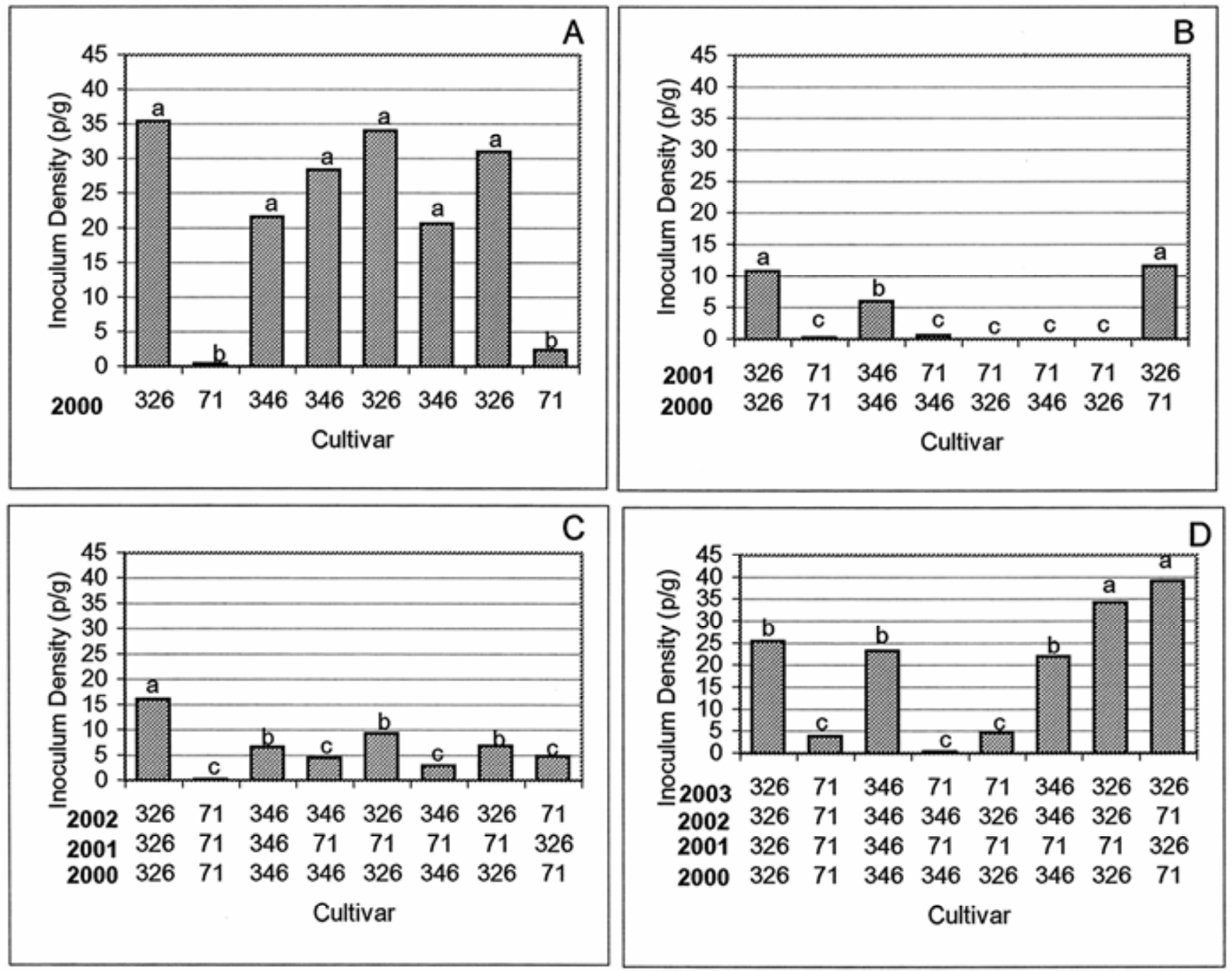

Fig. 2. A-D, Pathogen population density from 2000 through 2003 at the Duplin County field. Bars are the average of five replications per treatment per season. Bars with the same letter do not differ significantly (Waller-Duncan $k=100$ ). 
Unless otherwise indicated, only significant $(P \leq 0.05)$ differences between treatment means are presented.

\section{RESULTS}

Disease control in the Duplin County field was dependent upon the cultivar deployed in a particular year (Fig. 1). Over all years, disease incidence was greatest where partial resistance (K 326 and K 346) was deployed continuously, and it was lowest where complete resistance (NC 71) was deployed continuously or in rotation with the high level of partial resistance. In 2000, disease incidence ranged from 0.8 to 93\% across all treatments and was highest (56 to 93\%) in K 326 and K 346 plots and lowest in NC 71 plots (0.8 to $1.7 \%$ ) (Fig. 1A). In 2001, a similar trend was observed in K 326 and K 346 continuous plots (treatments 1 and 3) with incidence at 82 and $56 \%$, respectively (Fig. 1B). Treatment 8 , a rotation treatment of $\mathrm{NC} 71$ and $\mathrm{K}$ 326, also had a high disease incidence $(59 \%)$. Incidence was very low in this treatment in 2000; however, in 2001, when the low level of partial resistance was deployed, disease incidence increased significantly. Disease incidence was lowest in treatments where NC 71 was deployed, ranging from 2 to $6 \%$. The rotation treatments planted with $\mathrm{NC} 71$ in 2001 were not significantly different than the NC 71 continuous treatment. In 2002, there was a residual effect of deployment of NC 71 from the previous year (Fig. 1C). Even though treatments 4 through 7 were planted with partial resistance, the disease levels were not significantly different than the NC 71 continuous treatment. In fact, disease levels were numerically lower for treatment 4 (a rotation of NC 71and K 346) than in the NC 71 continuous treatment, with 7 and $11 \%$ disease, respectively. Treatments where partial resistance was deployed continuously continued to have the highest black shank incidence (about 80\%) in 2002 (Fig. 1C). Trends in disease incidence data were not as easy to ascertain in 2003 (Fig. 1D). In general, disease was not observed until late in the season, which was attributed to a very wet growing season $(>61 \mathrm{~cm}$ of rainfall) and little drought stress on the plants. The highest levels of disease were observed in treatments 1,7 , and 8 , where two of the three NC 71-K 326 treatments were not significantly different than continuous deployment of K 326 . The K 346 continuous plots had less disease than the K 326 continuous plots this year. The lowest disease ( 2 to $4 \%$ ) was observed with treatments 2,4 , and 5 . The rotation of NC 71K 346 did not differ from the continuous use of complete resistance in three of the four years (Fig. 1B, C, and D).

In general, inoculum densities (IDs) followed a pattern similar to disease incidence (Figs. 1 and 2). Where disease incidence was high, ID was high and, in treatments with low disease incidence, IDs also were low. For example, in 2000, when disease incidence ranged from 57 to $93 \%$ in treatments 1 and 3 to 7, ID in these treatments ranged from 22 to 35 propagules per gram $(\mathrm{p} / \mathrm{g})$. Where disease incidence was low, treatments 2 and 8 $(<2 \%)$, ID values from these two treat-
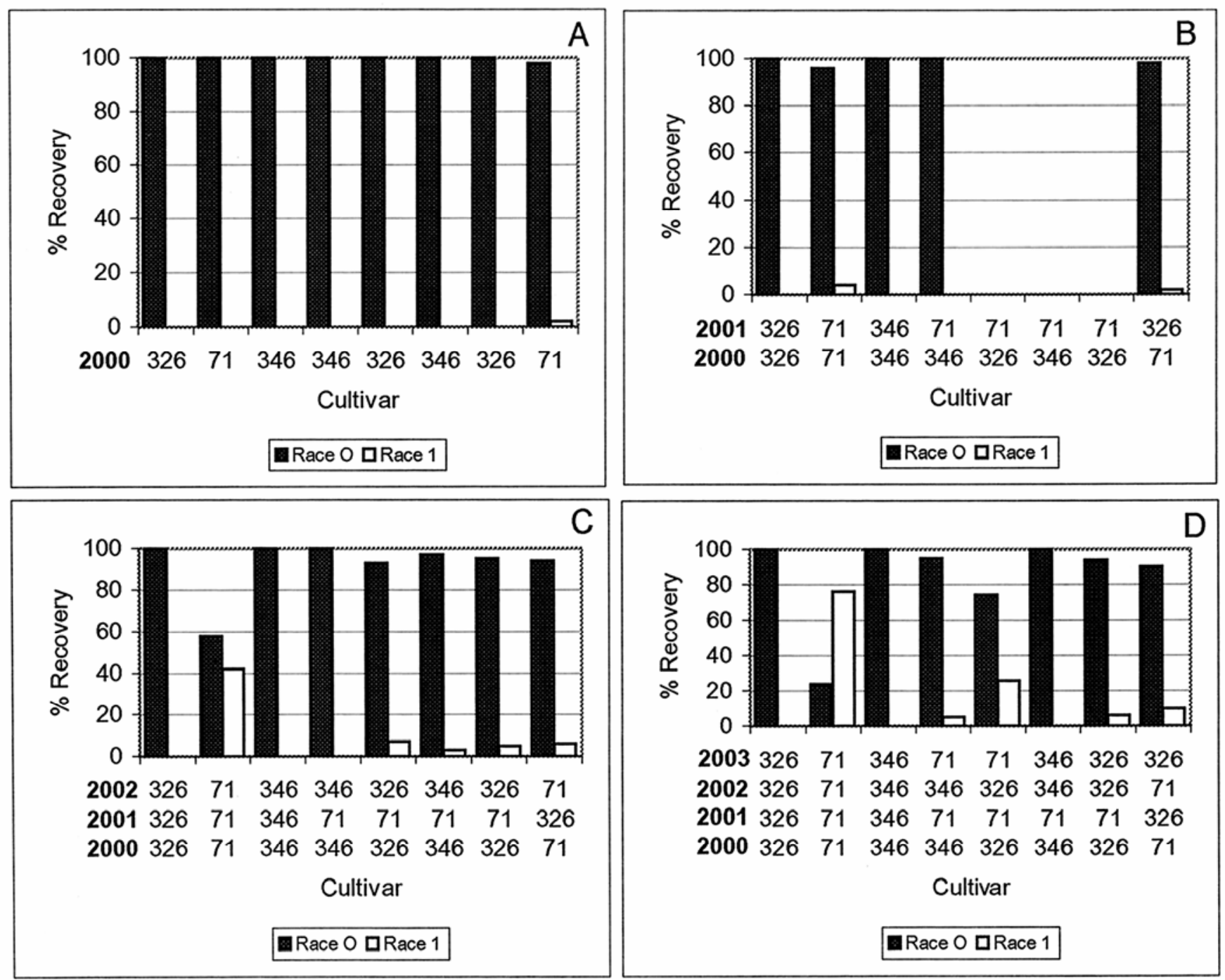

Fig. 3. A-D, Race profile of the Duplin County field from 2000 through 2003. Bars are the average of five replications (10 isolates/replication) for each treatment per year. 
ments were 0.4 and $2.4 \mathrm{p} / \mathrm{g}$, respectively (Figs. 1A and 2A). Inoculum densities dropped significantly in 2001 and 2002, with a maximum of 12 and $16 \mathrm{p} / \mathrm{g}$ (Fig. 2B and C). Both 2001 and 2002 were considered dry growing seasons in North Carolina. Inoculum densities rebounded in 2003 and were highest in treatments 7 and 8 (34 and $39 \mathrm{p} / \mathrm{g}$ ), rotation treatments of NC 71K 326; continuous K 326 and K 346 treatments were more intermediate (23 and 25 $\mathrm{p} / \mathrm{g}$ ), and the lowest ID was observed in treatments 2,4 , and $5(3,0.4$, and $5 \mathrm{p} / \mathrm{g})$, which were the continuous NC 71 plot and the NC 71-K346 rotation plots (Fig. 2D).

The race profile varied over years and also was dependent on the rotation treatment (Fig. 3). In spring 2000 baseline samples collected prior to transplanting, no race 1 isolates were detected in the 109 isolates assayed. After the first growing season, a single isolate of race 1 was recovered out of 450 isolates collected and screened in the fall of 2000 . The race 1 isolate was recovered from an NC 71 plot (Fig. 3A). At the end of the second grow- ing season, race 1 was recovered from additional plots representing treatments 2 and 8 , the $\mathrm{NC} 71$ continuous and the $\mathrm{NC}$ 71-K326 rotation treatments (Fig. 3B). At the end of the third year, race 1 was recovered from 5 of the 8 treatments $(2,5,6,7$, and 8), all of which had NC 71 in their planting history. No race 1 was recovered from the rotation treatment of high partial resistance with complete resistance. By the end of the third year, $42 \%$ of the isolates from continuous NC 71 plots (treatment 2) were race 1 , where initially no race 1 was recovered. During 2003 (Fig. 3D), race 1 once again was recovered from 5 of the 8 treatments and constituted $76 \%$ of the population recovered in treatment 2 . In the continuous NC 71 plots, the pathogen population shifted from $100 \%$ race 0 initially to $76 \%$ race 1 by the end of year four. Several rotation treatments, particularly the NC 71-K 346 rotation, gave good disease control with very little race 1 development (Figs. 1 and 3).

The spatial dynamics of race 1 development in the Duplin County field were examined by mapping the occurrence of race 1 over years. After the first year, there was a single isolate recovered, but by the end of year 2, race 1 isolates were recovered in three distinct areas on opposite sides of the field. After the third year, there were 12 occurrences of race 1 that were across the length and width of the field. In year four, race 1 was recovered from an additional two plots.

Similar results in disease control and shifts in race structure were obtained in the mixed-race field in Edgecombe County. A notable exception was that the lowest disease was observed with the high level of partial resistance in addition to the NC 71K346 rotation treatment. During 1998, disease was highest where K326 was planted (ranging from 98 to $99 \%$ ) and was intermediate where K346 was planted $(45 \%)$ (data not shown). Disease incidence was lowest in plots planted to NC 71 and ranged from 25 to $39 \%$ (data not shown). During 1999, disease levels were highest where K 326 was planted (treatments 1,5 , and 7), with incidence ranging from 28 to
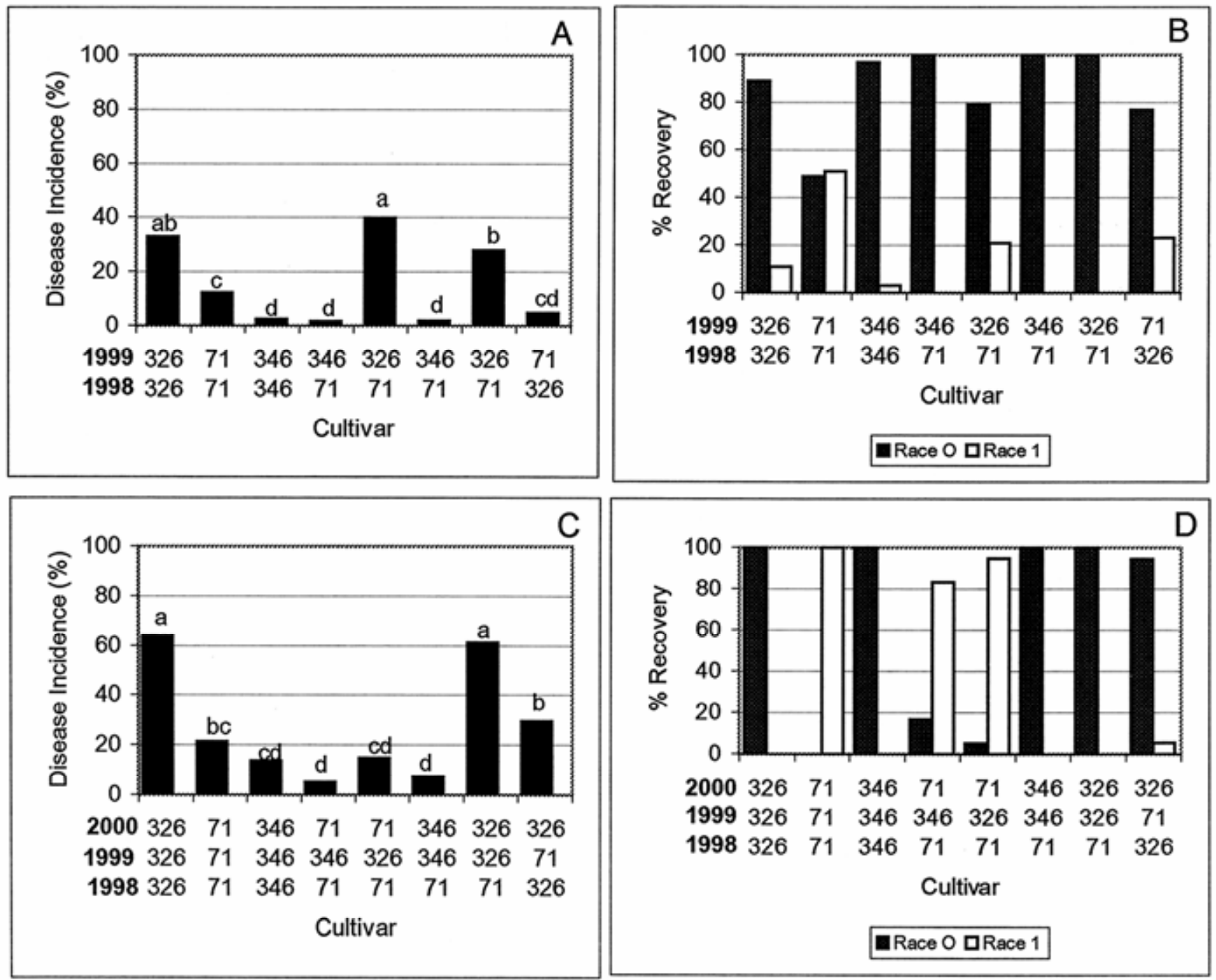

Fig. 4. Disease incidence and race profile during $\mathbf{A}$ and B, 1999 and $\mathbf{C}$ and D, 2000 at the Edgecombe County mixed-race field. Bars are the average of five replications per treatment per year. Bars with the same letter do not differ significantly (Waller-Duncan $k=100$ ). 
$33 \%$ (Fig. 4A). Incidence was intermediate where NC 71 was continuously deployed $(12 \%)$ and lowest in the treatments with continuous K 346 and rotations of NC 71$\mathrm{K}$ 346. In 2000, similar trends were observed across treatments, although disease incidence was higher in all treatments (Fig. 4C). Disease levels were highest where $\mathrm{K}$ 326 was deployed continuously or in rotation, intermediate where $\mathrm{NC} 71$ was deployed continuously, and lowest where K346 was deployed either continuously or in rotation with $\mathrm{NC} 71$. The rotation treatments of K 346 and NC 71 were numerically lower than the K 346 continuous treatment. At the end of the 1999 growing season, race 1 was recovered from 5 of the 8 treatments (Fig. 4B). Four of the five treatments $(1,2,5$, and 8$)$ were planted to either K 326 or NC 71. Although a low percentage of race 1 was recovered from plots planted with continuous K 346 in 1999 , race 1 was not recovered from this treatment after the third year of the study (Fig. 4B and D). In 1999, 51\% of the isolates recovered were race 1 after only 2 years of continuous deployment of NC 71 (Fig. 4B). Isolates from this treatment were $100 \%$ race 1 after 3 years of continuous NC 71. After three consecutive years of planting either the low or high level of partial resistance (treatments 1 and 3), race 1 was not recovered (Fig. 4D).

Disease incidence in the Guilford County field was lower than the Duplin and Edgecombe County fields, ranging from 0.6 to $11 \%$ in 2000 and from 0 to $19 \%$ in 2001 (Fig. 5A and B). The field previously had been cropped to tobacco. Disease was highest where K 326 and NC 71 were deployed. The lowest disease level was where K 346 was deployed in both years. In a spring 2000 baseline prior to transplanting, soil samples were collected and 89 isolates were recovered. Of the 89 isolates, 84 were race 1 (Fig. 6A); thus, the field population of $P$. parasitica var. nicotianae was predominately race 1 prior to the study. The five race 0 isolates were found in plots designated to be treatments 4,5 , and 8 . At the end of the first growing season, race 0 was no longer recovered from treatments 4 and 5, both of which were planted to NC 71 (Fig. 6B). However, at the end of the first season, race 0 was recovered from plots where partial resistance was deployed. In treatment 3 , no race 0 was recovered in the spring baseline; however, by the end of the first growing season, $20 \%$ of the isolates were race 0 . This trend continued into 2001, where isolates from treatment 3 were $30 \%$ race 0 (Fig. 6C). Additional race 0 was recovered from treatments 1,4 , and 6 , where both low and high levels of partial resistance were deployed (Fig. 6C).

\section{DISCUSSION}

The increase in predominance of race 1 of $P$. parasitica var. nicotianae in the flue- cured region of North Carolina has corresponded with the widespread deployment of cultivars with the $P h$ gene that confers complete resistance to race 0 of the pathogen. Results of this study illustrated that deployment of the $P h$ gene had a highly significant effect on the race structure of $P$. parasitica var. nicotianae in three fluecured tobacco fields in North Carolina with different initial race population structures. Race 1 increased in Duplin County from 0 to $76 \%$ and in Edgecombe County from 51 to $100 \%$, and it continued to predominate in Guilford County, when the $P h$ gene was deployed continuously, indicating the high degree of selection pressure the $P h$ gene exerts on the pathogen population. Results of these studies also showed that the rate of change to race 1 was dependent on the initial population structure of races in the field. For example, the rate of change in the Duplin County field, where no race 1 originally was detected, was much slower than in the Edgecombe County field, where both races originally were present in high percentages. The percentage of race 1 remained $100 \%$ in Guilford County and did not change in plots where the $P h$ gene was deployed.

Changes in the race structure of the soilborne pathogens Verticillium dahliae and $P$. sojae also have been reported fol- lowing the deployment of single-gene resistance $(4,26,27)$. Resistance to race 1 of Verticillium wilt pathogen of tomato, $V$. dahliae and $V$. albo-atrum, is conferred by the single, dominant $V e$ gene. Race 2 of $V$. dahliae was observed soon after the Ve gene was deployed in tomato cultivars and was thought to be a naturally occurring component of the field populations of $V$. dahliae (4). Thirteen resistance genes (Rps) at seven loci that confer complete or partial resistance to $P$. sojae have been characterized and, since 1955,45 pathogen races have been classified after the widespread deployment of various soybean cultivars with Rps genes for resistance. Many more isolates with unique virulence patterns have been identified but not given a race number $(26,27)$.

Race 1 of $P$. parasitica var. nicotianae was recovered after a single year of the deployment of the $P h$ gene in the Duplin County field, where initially no race 1 was recovered. Johnson et al. (15) identified the origin of the $P h$ gene in C $371-\mathrm{G}$ to be from N. plumbaginifolia. Apple (3) also recovered race 1 after a single year of planting NC 1071, a breeding line with the $N$. plumbaginifolia gene (3). The results of our study and Apple's study suggest that race 1 probably is a naturally occurring component of the P. parasitica var. nico-
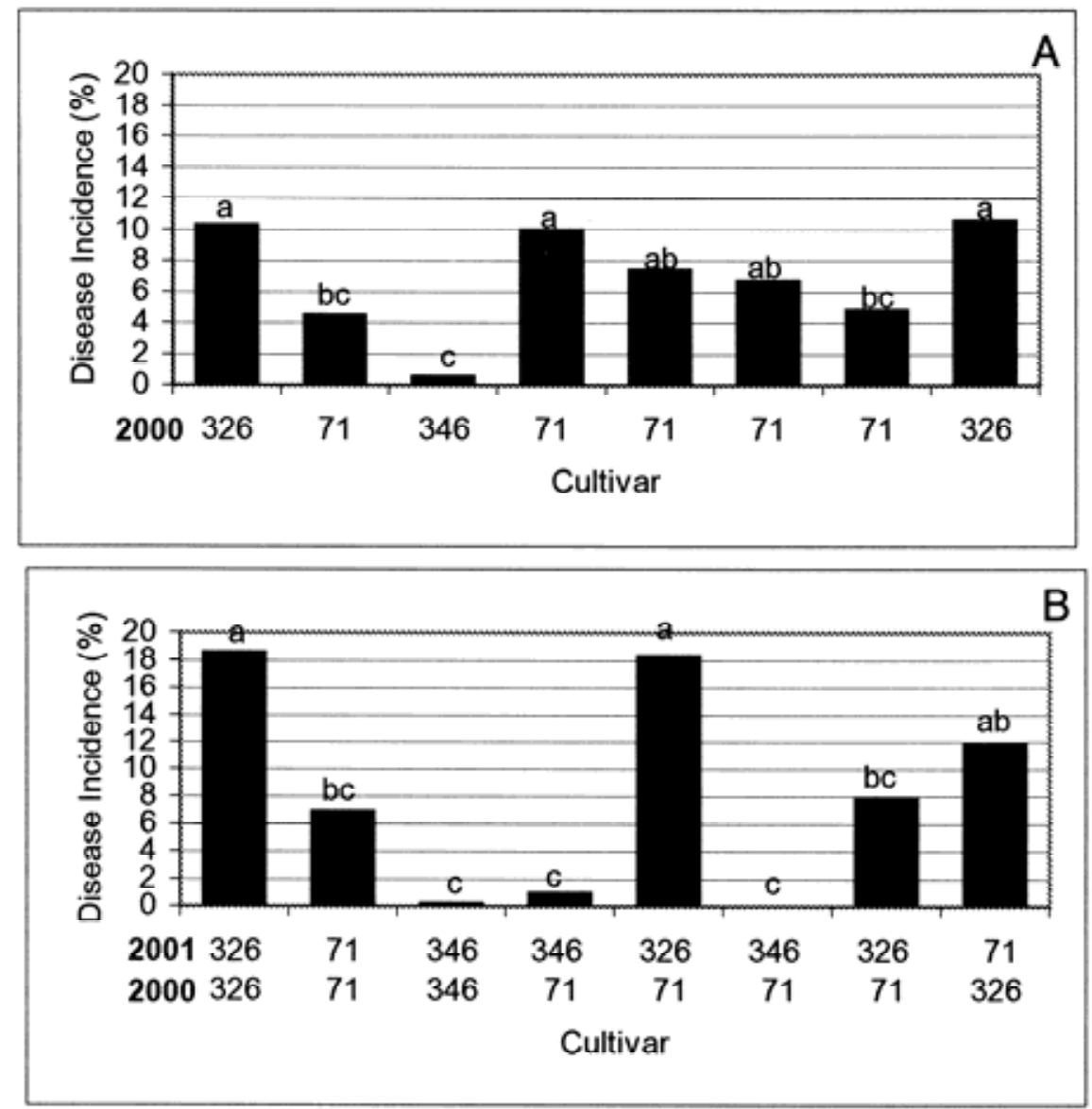

Fig. 5. Final disease incidence from A, 2000 and B, 2001 in the Guilford County predominately race 1 field. Bars are the average of six replications per treatment per season. Bars with the same letter do not differ significantly (Waller-Duncan $k=100$ ). 
tianae population. In Duplin County, the population of race 1 was present at levels that were below the detection limits of our soil assay in our initial spring baseline study. One year of resistance gene deployment may be sufficient to allow for build up of the race to a detectable level. Similarly, Bender and Shoemaker (4) found race 1 of $V$. dahliae in fields that had not yet been planted with cultivars that contained the $V e$ gene, indicating that the variant was a natural component of the pathogen population. Niederhauser (22) also reported races of $P$. infestans that could attack potato cultivars with combina- tions of major resistance genes, even though the cultivars had not been deployed previously in that area, again indicating that multiple avirulence genes probably are present in the pathogen population.

Studying a soilborne pathogen with limited dispersal in large plots over time allowed us to examine the spatial dynamics of race 1 development in Duplin County. Race 1 initially was recovered from a single plot; however, by the end of the second growing season, it was found in three discrete areas on opposite sides of the field. Because the plots were not contiguous, we feel that the occurrences of race 1 were not
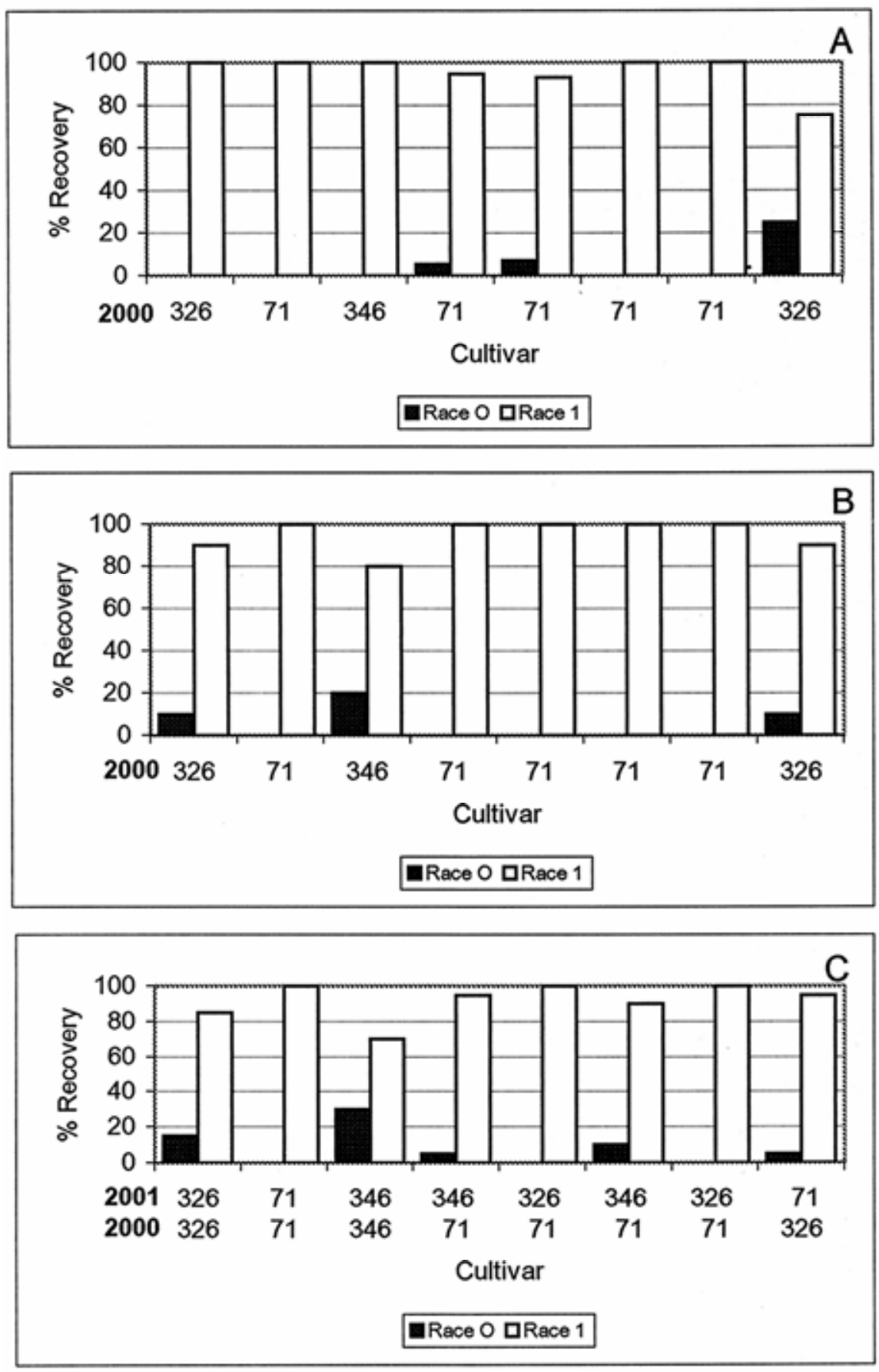

Fig. 6. Race profile from Guilford Co. A, preseason 2000, B, fall 2000, and C, fall 2001. Bars are the average of six replications (10 isolates/replication) for each treatment per year.

from movement of soil by farm equipment into new areas of the field, but represented at least three independent events of race 1 development in the population. Studies are in progress to examine the variability of these isolates.

Apple (3) also noted that, in 1961, all isolates recovered from the diseaseresistant breeding line NC 1071 were race 1 , illustrating the high degree of selectivity of complete resistance. Similar results were observed in this study, where race 1 only increased in treatments that included complete resistance. The increase in race 1 relative to race 0 on the completely resistant cultivar can be explained by examination of the mechanism of resistance. Complete resistance prevents growth and reproduction of the pathogen, which results in a sharp decline in the pathogen population $(24,29)$. Based on the rapid decline observed in race 0 populations in NC 71 plots, race 1 had a selective advantage that allowed it to become the predominant member of the population during continuous use of complete resistance.

Apple (3) observed that all isolates recovered from partially resistant lines were race 0 . Similar results were observed in this study, where race 0 either increased (Guilford County) or continued to predominate on cultivars with partial resistance (Duplin and Edgecombe Counties). In fact, after 3 years of continuous deployment of either level of partial resistance in Edgecombe County, race 1 no longer could be recovered from soil assays. In Guilford County, the predominately race 1 field, race 0 was recovered only from plots where partial resistance was deployed during both growing seasons. Race 0 increased from 0 to $30 \%$ of the population where the high level of partial resistance was deployed during the two growing seasons, but initially was not detected from that treatment. These results suggest that race 0 is more parasitically fit than race 1 on genotypes with partial resistance and may be a more aggressive pathogen than race 1 (31). In contrast to complete resistance, partial resistance does not totally prevent the growth and reproduction of the pathogen. Partial resistance reduces lesion number, slows the rate of root colonization, and reduces inoculum production by $P$. parasitica var. nicotianae, resulting in a reduction in the rate of epidemic development $(6,29)$. Race 1 may be at a competitive disadvantage to race 0 except in the presence of a host plant completely resistant to race 0 . Race 0 was the predominant race in most tobacco-growing areas throughout the world prior to the deployment of $N$. plumbaginifolia and $N$. longiflora genes for resistance to black shank (18).

The mechanism of complete resistance coupled with reduced fitness of race 1 isolates may explain why a rotation that alternates a high level of partial resistance 
and complete resistance is most effective in reducing disease losses and slowing changes in race structure. The complete resistance reduced race 0 populations and increased race 1 populations; however, by deploying partial resistance the next year, race 1 was at a competitive disadvantage compared with race 0 ; therefore, race 1 populations decreased. This would allow for complete resistance to be effective the following year against the developing race 0 population. Thus, a shift to race 1 may be advantageous to control of this disease, especially if growers follow a resistancegene rotation scheme as outlined in this study. A similar situation was observed with race 1 and race 2 of $V$. dahliae. Isolates of race 1 caused greater losses than race 2 on cultivars susceptible to both races, which implied a loss in aggressiveness in race 2 and a direct cost to the pathogen of added virulence (4). The loss of fitness in race 1 of $P$. parasitica var. nicotianae could be due to reduced pathogenic fitness (aggressiveness) or reduced ecological fitness (survival) and is the subject of another study (31).

In the Duplin County field, K 346 had been planted multiple years prior to this study. The extremely low level of disease in NC 71 plots illustrated the effectiveness of complete resistance when deployed where the $P$. parasitica var. nicotianae population is race 0 . In contrast, disease incidence in 2000 was very high in all treatments where partial resistance was planted, indicating the presence of a very aggressive race 0 population. Dukes and Apple (12) showed that aggressiveness of isolates increased after passage through a resistant cultivar compared with passage through a susceptible cultivar. Their study suggested that, under field conditions, more highly aggressive pathogen strains evolve as a result of continuous planting of a cultivar with a high level of partial resistance from Fla. 301. The components of increased aggressiveness identified by Dukes and Apple (13) have not been examined for the isolates from this field. The gradual reduction in effectiveness of partial resistance due to increased pathogen aggressiveness also suggests that rotating the two types of resistance may be the best approach for managing the disease and pathogen population and prolonging the effectiveness of both types of resistance. There are other economic considerations in the selection of a cultivar for use in areas with black shank present. For example, in many years and in many locations, K 346, with high partial resistance, yields less and has lower gross value than either K 326 or NC 71 (30). Therefore, some growers may decide to rotate cultivars with complete resistance with a high-value cultivar with low partial resistance and use multiple fungicide applications in preference to selecting a cultivar with high partial resistance with lower total value. This strategy also would allow the pathogen population to shift back to race 0 , but more slowly than if cultivars with high partial resistance were used, and have the added advantage of not selecting for highly aggressive strains of the pathogen.

At the end of the fourth season of the study in Duplin County, inoculum densities were higher in NC 71-K 326 rotation treatments than in K 326 continuous treatments. Samples were taken at the end of the growing season after the last harvest, when populations of $P$ parasitica var. nicotianae are highest. In addition, plants in the rotation treatments developed symptoms later than plants in the continuous treatments (i.e., the plants lived longer). This can be illustrated by looking at the area under the disease progress curve date (AUDPC), where the AUDPC was highest for the continuous K 326 treatment and lowest for the NC $71-\mathrm{K} 326$ rotation treatments (data not shown). When the AUDPC is computed, disease occurring early in the season is weighted more heavily than disease later in the season; thus, in the K326 continuous treatment, disease was present earlier in the season than in the rotation treatments. Pathogen reproduction is suppressed when plants die early in the season. Even in 2001 and 2002, when propagules per gram where much lower than the previous season, inoculum density ranged from 0 to $16 \mathrm{p} / \mathrm{g}$. According to Kannwischer and Mitchell (17), 0.5 p/g resulted in 93 to $100 \%$ mortality of Hicks, a susceptible cultivar. Therefore, in most treatments, ID values far exceeded the level needed to initiate epidemics of the disease.

Nematicides were applied at the Edgecombe County and Duplin County sites to control root knot nematodes. All cultivars used in this study have resistance to races 1 and 3 of the southern root knot nematode (Meloidogyne incognita). Galled roots were observed at both the Edgecombe County and Duplin County sites, indicating the presence of other races of $M$. incognita or another Meloidogyne sp. Nusbaum and Chaplin (23) found the incidence of the black shank disease to be reduced in a resistant cultivar following the application of a nematicide, and suggested that root injury caused by plant-parasitic nematodes can alter the expression of resistance. Because the severity of black shank can be greatly increased in the presence of plant-parasitic nematodes (25), a fumigant nematicide was used to suppress the effects of the nematode in these fields. Although some broad-spectrum fumigants also can reduce the populations of $P$. parasitica var. nicotianae, the effects of the fumigant would be similar across races of the pathogen and, thus, would allow a better evaluation of host resistance affects on the population dynamics and race structure of the pathogen.

This study illustrated that the race structure of the tobacco black shank pathogen could be managed by deploying multiple sources of resistance while achieving effective levels of disease control. Apple (3) recognized that complete resistance would be beneficial when used in combination with other sources of resistance with a broader genetic base of resistance (i.e., partial resistance) to control the black shank disease. Combining high levels of partial resistance with the $P h$ gene should provide resistance to both races of $P$. parasitica var. nicotianae and should be the goal of a future breeding program. This and another study also illustrated that there were differences in the fitness of races 0 and 1 and that race 1 is less aggressive than race 0 (31). In terms of total disease losses due to black shank, a shift to race 1 may not present an unworkable problem. Although a race shift to race 1 would make the $P h$ gene of limited value in American flue-cured tobacco production, the race shift could make the partial resistance mechanism more effective in controlling a parasitically weakened pathogen as was demonstrated by the present study, where rotation of sources of resistance led to decreased levels of disease. The occurrences of race 1 in the Duplin County field indicated that multiple occurrences of a new race are possible within a pathogen population, and investigation of the variation within the newly developed race 1 population should provide clues as to the nature of race development in this pathogen.

\section{ACKNOWLEDGMENTS}

We thank D. Glover, A. Broadwell, J. Wilson, C. Reuter, and J. Chatham for technical support; tobacco growers M. Wallace in Duplin County and R. Lewis in Guilford County for their cooperation; and the staff of the Upper Coastal Plain Research Station.

\section{LITERATURE CITED}

1. Apple, J. L. 1962. Physiological specialization within Phytophthora parasitica var. nicotianae. Phytopathology 52:351-354.

2. Apple, J. L. 1963. Persistence of Phytophthora parasitica var. nicotianae in soil. Plant Dis. Rep. 47:632-634.

3. Apple, J. L. 1967. Occurrence of race 1 of Phytophthora parasitica var. nicotianae in North Carolina and its implications in breeding for disease resistance. Tob. Sci. 11:79-83.

4. Bender, C. G., and Shoemaker, P. B. 1984 Prevalence of Verticillium wilt of tomato and virulence of Verticillium dahliae race 1 and race 2 in western North Carolina. Plant Dis. 68:305-309.

5. Cameron, D. R. 1959. The monosomics of Nicotiana tabacum. Tob Sci. 3:164-166.

6. Carlson, S. R., Wolff, M. F., Shew, H. D., and Wernsman, E. A. 1997. Inheritance of resistance to race 0 of Phytophthora parasitica var. nicotianae from the flue-cured tobacco cultivar Coker 371-Gold. Plant Dis. 81:1269-1274.

7. Chaplin, J. F. 1962. Transfer of black shank resistance from Nicotiana plumbaginifolia to flue-cured N. tabacum. Tob. Sci. 6:184-189.

8. Chaplin, J. F. 1966. Comparison of tobacco black shank resistance from four sources. Tob. Sci. 10:55-58.

9. Csinos, A. S., and Bertrand, P. F. 1994. Distribution of Phytophthora parasitica var. nicotia- 
nae races and their sensitivity to metalaxyl in Georgia. Plant Dis. 78:471-474.

10. Csinos, A. S., Fortnum, B. A., Powell, N. T., Reilly, J. J., and Shew, H. D. 1984. Resistance of tobacco cultivars and candidate cultivars to Phytophthora parasitica var. nicotianae. Tob. Sci. 28:153-155.

11. Csinos, A. S., and Minton, N. A. 1983. Control of tobacco black shank with combinations of systemic fungicides and nematicides or fumigants. Plant Dis. 67:204-207.

12. Dukes, P. D., and Apple, J. L. 1961. Influence of host passage on virulence of Phytophthora parasitica var. nicotianae. Plant Dis. Rep. 45:362-365.

13. Dukes, P. D., and Apple, J. L. 1962. Relationship of zoospore production potential and zoospore motility with virulence in Phytophthora parasitica var. nicotianae. Phytopathology 52:191-193.

14. Fisher, L. R., and Priest, J. A. 2003. Topping and sucker management and use of ethephon. Pages 106-130 in: 2004 Flue-Cured Tobacco Information. N. C. Coop. Ext. Serv. Bull. AG187 (revised).

15. Johnson, E. S., Wolff, M. F., Wernsman, E. A., Atchley, W. R., and Shew, H. D. 2002. Origin of the black shank resistance gene, $\mathrm{Ph}$, in tobacco cultivar Coker 371-Gold. Plant Dis. 86:1080-1084.

16. Jones, K. J., and Shew, H. D. 1995. Early season root production and zoospore infection of cultivars of flue-cured tobacco that differ in level of partial resistance to Phytophthora parasitica var. nicotianae. Plant Soil 172:55-61.

17. Kannwischer, M. E., and Mitchell, D. J. 1978.
The influence of a fungicide on the epidemiology of black shank of tobacco. Phytopathology 68:1760-1765.

18. Lucas, G. B. 1975. Diseases of Tobacco, 3rd ed. Biological Consulting Associates, Raleigh, NC.

19. Melton, T. A., and Broadwell, A. 2003. Disease Management. Pages 142-166 in: 2004 Flue-Cured Tobacco Information. N. C. Coop. Ext. Serv. Bull. AG-187 (revised).

20. Moore, E. L., and Powell, N. T. 1959. Dominant and modifying genes for resistance to black shank of tobacco. (Abstr.) Phytopathology 49:318.

21. Morton, H. V., and Urech, P. A. 1988. History of the development of resistance to phenylamide fungicides. Pages 59-60 in: Fungicide Resistance in North America. C. E. Delp, ed. American Phytopathological Society, St. Paul, MN

22. Niederhauser, J. S., Cervantes, J., and Servin, L. 1954. Late blight in Mexico and its implications. Phytopathology 44:406-408.

23. Nusbaum, C. J., and Chaplin, J. F. 1952. Reduction of the incidence of black shank in resistant tobacco varieties by soil fumigation. (Abstr.) Phytopathology 42:15.

24. Parlevliet, J. E. 1979. Components of resistance that reduce the rate of epidemic development. Annu. Rev. Phytopathol. 17:203-222.

25. Powell, N. T., and Nusbaum, C. J. 1960. The black shank-root knot complex in flue-cured tobacco. Phytopathology 50:899-906.

26. Ryley, M. J., Obst, N. R., Irwin, J. A. G., and Drenth, A. 1998. Changes in the racial composition of Phytophthora sojae in Australia between 1979 and 1996. Plant Dis. 82:10481054.
27. Schmitthenner, A. F. 1985. Problems and progress in control of Phytophthora root rot of soybean. Plant Dis. 69:362-368.

28. Shew, H. D. 1983. Effects of soil matric potential on infection of tobacco by Phytophthora parasitica var. nicotianae. Phytopathology 73:1160-1163.

29. Shew, H. D., and Shew, B. B. 1994. Host Resistance. Pages 244-275 in: Epidemiology and Management of Root Diseases. C. L. Campbell and D. M. Benson, eds. SpringerVerlag, Heidelberg, Germany.

30. Smith, W. D., Fisher, L. R., Tart, G., and Barnes, K. 2003. Variety Information. Pages 13-36 in: 2004 Flue-Cured Tobacco Information. N. C. Coop. Ext. Serv. Bull. AG-187 (revised).

31. Sullivan, M. J., Melton, T. A., and Shew H. D. 2003. Managing the race structure of the tobacco black shank pathogen (Abstr.). American Phytopathological Society Southern Division Abstracts: 20-21. Publication No. 2004 0033-SOA.

32. Tisdale, W. B. 1931. Development of strains of cigar wrapper tobacco resistant to black shank (Phytophthora nicotianae Breda de Haan). Fla Agric. Exp. Stn. Bull. 226:1-45.

33. Valleau, W. D., Stokes, G. W., and Johnson, E. M. 1960. Nine years' experience with the Nicotiana longiflora factor for resistance to Phytophthora parasitica var. nicotianae in the control of black shank. Tob. Sci. 4:92-94.

34. Wernsman, E. A., Matzinger, D. F., and Powell, N. T. 1974. Genetic investigations of intraspecific and interspecific sources of black shank resistance in tobacco. Tob. Sci. 18:1518 . 